УДК 378.147:373.67

DOI:

Мирослава Вашкевич, магістр, початкової та дошкільної освіти Міжнародного економіко-гуманітарного університету імені академіка Степана Дем'янчука

\title{
ПІДГОТОВКА МАЙБУТНІХ ВЧИТЕЛІВ ПОЧАТКОВОЇ ШКОЛИ ДО ВПРОВАДЖЕННЯ НЕСТАНДАРТНИХ ТЕХНІК ЗОБРАЖЕННЯ НА УРОКАХ ОБРАЗОТВОРЧОГО МИСТЕЦТВА
}

Впровадження нетрадииійних технік зображення на уроках образотворчого мистецтва сприяє розвитку творчих здібностей дітей, і вимагає вмілого педагогічного впливу. Підготовка майбутніх вчителів до впровадження нетрадиційних технік зображення на уроках образотворчого мистецтвв включає: опанування вміннями і навичками з керівниитва художньо-творчою діяльністю дітей; формування практичних навичок використання нетрадиційних технік у ході образотворчої діяльності; засвоєння передового педагогічного досвіду; підвищення майстерності протягом життя.

Ключові слова: професійна підготовка; майбутні вчителі; нетрадиційні техніки зображення; урок образотворчого мистеиттва; творчі здібності.

Jim. 12.

Muroslava Vashkevuch, Master of Elementary and Preschool Education, International University of Economics and Numanities named after Academician Stepan Demyanchuk

\section{TRAINING OF FUTURE TEACHERS OF THE PRIMARY SCHOOL FOR IMPLEMENTATION OF NON-STANDARD IMAGE TECHNOLOGIES FOR EDUCATIONALART STUDIES}

The current state of development of art education requires high-quality training of future teachers to use nontraditional image techniques in elementary school. Teaching children the different techniques of drawing, mastering various materials, ways of working with them are very important for the development of creativity of junior schoolchildren, provide an opportunity to more effectively transfer images in their impressions of the surrounding life. Non-traditional imaging techniques contribute to the development of the creative potential of the child, enhancing its creative abilities; stimulate manifestations of autonomy, initiative, expression of the individuality of children in creative activity; the establishment of effective communicative interaction with children during joint artistic and creative activities.

The introduction of non-traditional imaging techniques in fine arts lessons in elementary school requires the skillful influence of a teacher, who must manage the artistic and creative process of children. The purpose of the article is the disclosure of the features of training future teachers to introduce non-standard image techniques in the fine arts lessons in elementary school.

The training of future primary school teachers to the introduction of non-traditional imaging techniques in fine arts lessons includes: mastering the knowledge, skills and abilities to guide the artistic and creative activities of children; the formation of skills to use non-traditional techniques of the image in the course of graphic activity during practical and laboratory classes, independent work, imitation of the actions of university teachers; acquaintance with the pedagogical experience of the organization of non-traditional graphic activity of pupils in elementary school; self-improvement and enhancement of pedagogical skills throughout life. The prospect is to create a model of the formation of readiness of future teachers to introduce non-standard image techniques in the fine arts lessons in elementary school.

Keywords: professional training; future teachers; non-traditional techniques of the image; a lesson of the fine arts; creative abilities.

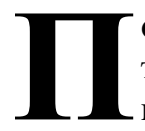

остановка проблеми. Сучасні тенденції розвитку мистецької освіти потребують удосконалення підготовки та розвитку професійних умінь і навичок вчителя початкової школи, який викладає дисципліни художньо-естетичного циклу. Реалізація завдань естетичного виховання дітей висуває особливі вимоги до професійної підготовки майбутніх вчителів, готових до реалізації свого творчого потенціалу у педагогічній діяльності, до впровадження нестандартних технік і методик роботи з учнями.
Цінним засобом у розвитку творчих здібностей дітей молодшого шкільного віку на уроках образотворчого мистецтва $є$ використання нетрадиційних технік зображення. Нетрадиційна образотворча діяльність відіграє важливу роль у загальному психічному розвитку дитини, адже цінним $є$ не кінцевий продукт - малюнок, а розвиток особистості, активізація творчості, ідентифікація ії у творчій роботі.

Завдяки використанню нетрадиційних технік малювання на заняттях $з$ молодшими школярами вчителю вдається розкрити внутрішній світ 


\section{ПІДГОТОВКА МАЙБУТНІХ ВЧИТЕЛІВ ПОЧАТКОВОЇ ШКОЛИ ДО ВПРОВАДЖЕННЯ НЕСТАНДАРТНИХ ТЕХНІК ЗОБРАЖЕННЯ НА УРОКАХ ОБРАЗОТВОРЧОГО МИСТЕЦТВА}

дитини, відчути іiї своєрідність та неповторність, визначити її психічний та емоційний стан, сприятливість соціального оточення, ресурсний потенціал, приховані комплекси, страхи чи проблеми (Н. Бойко, Т. Обертас та ін.). Образи, що виникають в уяві і фіксуються дитиною на папері, здатні допомогти дітям виявити та передати досить безпечним способом всі ті пригнічені почуття, думки, прагнення та бажання, що приховуються ними десь глибоко в душі.

Зважаючи на вищевказане, майбутні педагоги початкової школи мають бути готові до використання нетрадиційних технік малювання на уроках образотворчого мистецтва, активного розвитку творчого потенціалу дітей. Разом з тим вчителі початкових класів потребують якісної та майстерної підготовки, а сучасні тенденції розвитку мистецької освіти, зокрема освітньої галузі “Мистецтво”, потребують удосконалення та розвитку професійних умінь учителя початкових класів, який викладає дисципліни художньо-естетичного циклу (О. Красовська, Г. Савчин, Ж. Ясеницька та ін.). Підтвердження нашої думки знаходимо у твердженнях Г. Падалки, яка зазначає, що до початкової школи прийти вчитель, що володіє широким спектром знань і вмінь 3 дисциплін художньо-естетичного циклу та сучасними методиками викладання, спрямованими на розвиток активності, ініціативності, креативності, самостійності, критичності учнів, здатний нейтралізувати зовнішні антихудожні впливи середовища та забезпечити умови для їхньої самореалізації, безперервного самовдосконалення, самовиховання [9, 24].

Аналіз основних досліджень і публікацій. Сучасний стан розвитку професійно-педагогічної підготовки майбутніх вчителів висвітлюється у працях відомих вчених О. Дубасенюка, І. Зязюна, В. Кременя, Н. Ничкало, О. Рудницької та ін. Психологічні засади професійного формування майбутнього педагога розкривають І. Бех, В. Бодров, В. Панок, В. Рибалка та ін. Особливості професійної та педагогічної освіти вивчаються науковцями Г. Васяновичем, В. Свтухом, С. Лісовою, А. Нісімчуком, Г. Яворською та ін.

Засади підготовки майбутніх педагогів до викладання мистецьких дисциплін розглядають С. Коновець, Л. Масол, С. Соломаха. Особливостям використання нетрадиційних засобів роботи 3 учнями, що сприяють розвитку їх творчих здібностей, приділено належну увагу у вітчизняній мистецькій педагогіці (М. Кириченко, М. Лещенко, Л. Масол, В. Орлов, Г. Падалка, О. Ростовський, О. Рудницька, О. Щолокова та ін.).

Методичним аспектам використання нетрадиційних технік зображення в образотворчій роботі з дітьми молодшого шкільного віку присвячені праці сучасних науковців і практиків Н. Бойко, С. Кельм, Ю. Криворучко, С. Коновець, О. Курилко, Л. Масол, Т. Обертас, Г. Падалки, Н. Погрібняк, Г. Сухорукової, В. Томашевського, О. Шклярової, Л. Янцур, та ін.

Водночас недостатньо уваги приділяється безпосередній підготовці майбутніх вчителів початкових класів до використання нетрадиційних технік зображення на уроках образотворчого мистецтва. Відповідно до вищевказаного метою даної статті $\epsilon$ розкриття особливостей підготовки майбутніх вчителів до впровадження нестандартних технік зображення на уроках образотворчого мистецтва у початковій школі.

Виклад основного матеріалу. Зміст підготовки майбутніх вчителів в закладах вищої педагогічної освіти визначається вимогами суспільства, рівнем розвитку педагогіки як науки, специфікою педагогічної діяльності в сучасному світі. Мета підготовки майбутніх вчителів полягає у формуванні вчителя, який володіє знаннями педагогічної теорії і практичними вміннями та навичками у сфері освіти і виховання.

Професійна підготовка майбутніх вчителів початкових класів до керівництва образотворчою діяльністю учнів реалізується як процес формування їх професійної компетентності на основі інтеграції психолого-педагогічного та художньо-творчого напрямів. Обидва ці напрями підготовки, на думку О. Красовської [4], Ж. Ясеницької [12], формують професійну компетентність майбутніх педагогів, яка дозволяє керувати процесом художньо-творчого розвитку школярів, а не просто навчати основам образотворчої грамоти.

Вчений Ф. Бандуристий розробив структурнофункціональну модель процесу професійної підготовки майбутніх вчителів початкової школи, що відображає структуру навчального процесу, основою якого є психолого-педагогічна i художньо-творча підготовки, інтегративним елементом виступає методична підготовка, здатна постійно змінюватися і вдосконалюватися залежно від рівня сучасної художньої освіти і виховання, потім перевірятися в процесі педагогічної практики в реальному навчальному процесі $[1,20]$.

Результатом $є$ формування професійної компетентності майбутнього вчителя образотворчого мистецтва, що включає художньо-педагогічну спрямованість, художньо-педагогічні компетенції, професійно значущі якості особистості, які $\epsilon$ основою здатності до керівництва художньо- 


\section{ПІДГОТОВКА МАЙБУТНІХ ВЧИТЕЛІВ ПОЧАТКОВОЇ ШКОЛИ ДО ВПРОВАДЖЕННЯ НЕСТАНДАРТНИХ ТЕХНІК ЗОБРАЖЕННЯ НА УРОКАХ ОБРАЗОТВОРЧОГО МИСТЕЦТВА}

творчою діяльністю школярів, передачі різноманітних видів досвіду, а в цілому - до загального розвитку особистості учня засобами художньо-творчої діяльності.

За свідченням Ю. Криворучко, підготовка майбутніх вчителів початкової школи до роботи на уроках образотворчого мистецтва повинна бути заснована на розкритті внутрішніх механізмів, що забезпечують успішність художньо-творчого процесу учнів (формування уявного образу роботи, його реалізація в матеріалі, критичний аналіз готової роботи і внесення змін). Також підготовка до керівництва образотворчою діяльністю учнів повинна формувати у майбутніх вчителів вміння моделювати процес творчості дітей, розвивати творчий підхід до процесу навчання образотворчому мистецтву (вибору завдань, методів і прийомів навчання), а не озброювати готовими методичними рекомендаціями. Важливим $\epsilon$ й усвідомлення майбутніми вчителями конкретних етапів процесу зображення, з одного боку, і через інтуїтивний підхід до створення образу, з іншого. Це стосується як творчості студентів, так і підходу до організації творчого процесу у школярів $[5,118]$.

Провідне місце в системі професійної підготовки вчителів початкової школи займає курс теорії і методики викладання уроків образотворчого мистецтва, що спрямований на формування готовності випускників до роботи 3 проведення уроків образотворчого мистецтва в початковій ланці.

На думку О. Красовської, дисципліна “Образотворче мистецтво 3 методикою викладання”, що включена до навчальних планів педагогічних факультетів гуманітарних університетів для успішної підготовки вчителів початкових класів, належить до фундаментальних, що формують професійні якості майбутніх педагогів початкових класів [4, 74].

Для підвищення якості підготовки майбутніх вчителів до уроків образотворчого мистецтва та використання нетрадиційних технік зображення I. Мужикова пропонує педагогам 3ВО у ході викладання дисципліни "Методика викладання образотворчого мистецтва” приділяти необхідну увагу засвоєнню студентами основних понять у галузі образотворчого мистецтва та у галузі організації образотворчої діяльності молодших школярів; створенню умов для активної художньої діяльності, спрямованої на сприймання і створення художніх образів та усвідомлення естетичної цінності результатів художньої діяльності учнів [7, 139].
Для цього у ході практичної діяльності із майбутніми вчителями початкових класів викладачі 3ВО мають організовувати безпосередній творчий процес, під час якого пояснювати, показувати, представляти зразки виконання, демонструючи послідовність етапів даного процесу. Викладачі, на думку I. Мужикової, мають приділяти належну увагу контролю за наслідуванням та дотриманням поетапності виконання завдань студентами, їх самостійному застосуванню набутих знань та вмінь на практиці. Великого значення I. Мужикова надає формуванню у майбутніх вчителів початкової школи основних понять образотворчого мистецтва, що доцільно організовувати за допомогою відвідування виставок творів сучасних митців та виставок дитячих робіт; грунтовного аналізу художніх творів 3 позицій відображення в них певного образу; перегляду, вивчення та аналізу дитячих малюнків. Все це комплексно забезпечує майбутніх вчителів практичними навичками організації образотворчої діяльності під час уроку з учнями та надає уявлення про критерії оцінювання дитячих робіт, створює міцну базу для творчого сприйняття творів молодших школярів [7, 139].

При цьому, як засвідчує Ю. Криворучко, традиційна методика підготовки вчителя початкової школи здебільшого орієнтує студентів на опанування алгоритмами проведення уроків і лише незначною мірою охоплює питання розвитку творчої особистості дитини та врахування їі здібностей в умовах традиційного навчання $[5,118]$.

Відтак, важливим в процесі підготовки майбутніх вчителів початкової школи до викладання образотворчого мистецтва є надання студентам необхідних знань та уявлень про специфіку впливу образотворчої діяльності на особистість молодшого школяра, а також формування у них навичок врахування цього впливу на творчі здібності дітей під час планування та проведення уроків. За свідченням Ю. Криворучко, у ході підготовки майбутніх вчителів початкової школи до уроків образотворчого мистецтва варто передбачити спеціальні види роботи з формування у них вмінь здійснювати педагогічне керівництво розвитком художньо-творчих здібностей учнів на основі врахування впливу образотворчої діяльності на особистість і творчі здібності дітей $[5,119]$.

У дослідженнях Н. Бойко [2], Т. Обертас [8] образотворча діяльність розглядається як важливий елемент гармонійного і творчого розвитку молодших школярів. Майбутній педагог має засвоїти, що у процесі занять з образотворчої 


\section{ПІДГОТОВКА МАЙБУТНІХ ВЧИТЕЛІВ ПОЧАТКОВОЇ ШКОЛИ ДО ВПРОВАДЖЕННЯ НЕСТАНДАРТНИХ ТЕХНІК ЗОБРАЖЕННЯ НА УРОКАХОБРАЗОТВОРЧОГО МИСТЕЦТВА}

діяльності у дітей інтегрально взаємодіють пізнавальна та продуктивна функції, що забезпечує процес переходу від засвоєння знань до їх самостійного застосування на практиці. Працюючи з різними матеріалами, молодші школярі мають можливість задовольнити потребу щодо створення чогось нового, змінити форму зображених предметів, дослідити їх можливості та властивості. Варіативність різних матеріалів, їх легка трансформація, постійна змінність та абстрактність сприяють вільному виявленню ініціативи, спонукають дітей до самостійності і творчого пошуку, сприяють формуванню у них пізнавальних інтересів [2, 117; 8, 120].

Навчання дітей техніці малювання, розуміння властивостей різних матеріалів, їх виражальних можливостей, формування вміння використовувати при створенні зображень різні матеріали дуже важливі для розвитку образотворчої творчості молодших школярів.

Т. Обертас вказує, що оволодіння різними матеріалами, способами роботи 3 ними, розуміння їх виразності надає дітям змогу ефективніше використовувати при відображенні в малюнках своїх вражень від навколишнього життя. Саме вивчення школярами різних технік сприяє їхньому розумовому розвитку, удосконаленню політехнічних уявлень про особливості й різноманітність технологічних прийомів роботи з матеріалами та інструментами, виявляє інтерес до одного або декількох видів образотворчої діяльності, допомагає вибрати для вирішення практичного завдання техніку, що відповідає індивідуальним особливостям і потребам учнів, зумовленим вродженими задатками [8, 124].

Цінним для розвитку дитячої творчості $€$ використання нетрадиційних технік зображення. За ствердженням цілої низки педагогів (Н. Бойко, Ю. Криворчуко, Т. Обертас, Ж. Ясеницька та ін.), нетрадиційні техніки малювання створюють на уроці образотворчого мистецтва умови, в яких учні починають самостійно мислити, висловлювати в малюнку свої почуття, думки, переживання, емоції, настрої, вчаться бачити в несподіваних поєднаннях кольорових плям і ліній образи та самостійно їх оформляти, все більше занурюючись у світ творчості.

Г. Сухорукова зауважує, що нетрадиційні техніки малювання є способом створення нового, оригінального витвору мистецтва, у якому гармонійно поєднуються все: і колір, і лінія, і сюжет. Завдяки нетрадиційним технікам малювання створюється атмосфера розкутості, відкритості, розвивається самостійність дітей, створюється емоційно-позитивне ставлення до діяльності [10, 140].

За ствердженням I. Ликової, нетрадиційна техніка зображення сприяє розвиткові у дитини дрібної моторики рук і тактильного сприйняття; просторового орієнтування на аркуші паперу, окоміру i зорового сприйняття; уваги й посидючості; образотворчих навичок і вмінь, спостережливості, естетичного сприйняття, емоційної чуйності $[6,55]$.

Вчитель під час використання нетрадиційних технік вчить дітей бачити прекрасне, розуміти й цінити твори мистецтва, красу і багатство рідної природи. Найбільш цінними, на нашу думку, є нетрадиційні техніки малювання, які сприяють розвитку у дітей творчості та уяви.

На основі аналізу методичних і практичних напрацювань цілої низки педагогів (В. Котляр, Н. Погрібняк, С. Кельм, О. Курилко, Г. Падалки, Г. Сухорукової, О. Шклярова, Н. Юркова та ін.), ми виділили найчастіше використовувані на уроках образотворчого мистецтва нетрадиційні техніки зображень: малювання відкритою долонькою та пальчиками, свічкою та аквареллю, мильними бульбашками, картоплею (штампування), ниткою (ниткографія), на зволоженому аркуші паперу, відбитками (“листочки замість пензлика"), малювання у техніці видування, техніка набризкування. Добре, коли молодший школяр не тільки знайомий з різними прийомами зображення, але і не забуває про них, а використовує, виконуючи задану ціль. Наприклад, більшість нетрадиційних технік зображення можна використовувати в одній - у колажі, коли при зображенні пейзажу школяр використовує точковий малюнок (трава), сонечко малює пальцем, пухнастих тварин малює поролоном, інших тварин вирізує з листівок, тканинами зображує небо і хмари тощо $[11,70]$.

При цьому варто відзначити, що успіх навчання нетрадиційним технікам багато в чому залежить від того, які методи і прийоми використовує педагог, щоб донести до дітей певний зміст. На початку уроку вчитель повинен познайомити дітей 3 тим чи іншим способом отримання зображення, пояснити і проаналізувати з учнями запропоновані зразки робіт, а потім продемонструвати застосування даної техніки на практиці [3, 22].

Відбиток печатками 3 картоплі може бути використаний на уроках декоративного малювання 3 метою відпрацювання поняття “ритм”, на уроках тематичного малювання i малювання 3 пам'яті і уяви - 3 метою виконання окремих елементів зображення. Деякі техніки, як кляксографія різних видів, набризк, відбитки листя 


\section{ПІДГОТОВКА МАЙБУТНІХ ВЧИТЕЛІВ ПОЧАТКОВОЇ ШКОЛИ ДО ВПРОВАДЖЕННЯ НЕСТАНДАРТНИХ ТЕХНІК ЗОБРАЖЕННЯ НА УРОКАХ ОБРАЗОТВОРЧОГО МИСТЕЦТВА}

можуть бути використані з метою підготовки аркуша паперу до подальшого зображення [3, 24].

Використання нетрадиційних технік зображення на уроках образотворчого мистецтва у початковій школі потребує відповідної підготовки вчителя та його педагогічної готовності до впровадження інновацій в процес творчої діяльності дітей. Т. Обертас вказує, щоб виховати творчу особистість молодшого школяра, вчителю необхідно удосконалюватися самому, переймати досвід кращих учителів, розвивати в собі творчість, постійно підвищувати професіоналізм, шукати нові шляхи активізації діяльності учнів на всіх етапах навчальної роботи, використовувати оригінальні форми пояснення матеріалу, впроваджувати нетрадиційні техніки малювання $[8,124]$.

За свідченням Ю. Криворучко, оптимальними формами організації навчального процесу 3 підготовки майбутніх вчителів до використання нетрадиційних технік $є$ : практичні, лабораторні заняття та самостійна робота студентів. Також доцільним $є$ використання інтерактивних методів навчання, методу проектів, творчих вправ, і прийомів створення проблемної ситуації, демонстрації, складання схем послідовності роботи $[5,120]$.

У процесі підготовки майбутніх вчителів до впровадження нетрадиційних технік зображення на уроках образотворчого мистецтва Ю. Криворучко пропонує використовувати інтерактивні методи навчання, а саме: дискусії, роботу в парах, ротаційні (змінювані) трійки, “Карусель”, роботу в малих групах, “Мікрофон”, “Мозковий штурм”, “Навчаючи - учусь”, аналіз ситуацій, розігрування ситуацій за ролями, що насамперед спрямовані на розвиток художньотворчих здібностей студентів та формування у них практичних умінь і навичок в галузі розвитку художньо-творчих здібностей молодших школярів [5, 120].

Цінним для підготовки студентів до впровадження нетрадиційних технік малювання на уроках з молодшими школярами є відвідання уроків образотворчого мистецтва, проведених досвідченими педагогами та їх обговорення; вивчення досвіду роботи вчителів та відвідання тематичних педрад з означеної проблематики; відвідання та прийняття участі в організації виставок творчих робіт учнів [5, 120].

Разом з тим підготовка майбутніх вчителів до викладання образотворчого мистецтва у початковій школі має продовжуватися й після закінчення ЗВО. Як влучно вказує Т. Обертас, учитель повинен учитися протягом усього життя, прагнучи досягти вершини своєї педагогічної майстерності [8, 124].

Висновки та перспективи подальших розвідок у цьому напрямі дослідження. Використання на уроках образотворчого мистецтва нетрадиційних технік малювання, що спрямоване на активізацію творчих здібностей учнів, потребує вдосконаленої підготовки майбутніх вчителів до роботи з ними. Підготовка майбутніх вчителів початкових класів до використання нетрадиційних технік зображення на уроках образотворчого мистецтва включає в себе: опанування знаннями, вміннями і навичками 3 керівництва художньотворчою діяльністю дітей; засвоєння особливостей впливу образотворчої діяльності на молодших школярів та врахування цього у ході організації навчальної роботи з ними; отримання теоретичних знань і практичних навичок використання нетрадиційних технік у ході практичних і лабораторних занять, самостійної роботи, наслідування дій викладачів 3ВО, відвідування уроків, проведених учителями у початковій школі, засвоєння передового педагогічного досвіду впровадження нетрадиційних технік образотворчої діяльності у роботі з учнями; самовдосконалення і підвищення педагогічної майстерності протягом всього життя.

Перспективним напрямом дослідження є створення моделі формування готовності майбутніх вчителів початкової школи до впровадження нестандартних технік зображення на уроках образотворчого мистецтва.

\section{ЛІТЕРАТУРА}

1. Бандуристый Ф. Оптимизация обучения художественному проектированию в системе специальной подготовки учителя изобразительного искусства в педвузах (университетах). Москва, $2001.315 \mathrm{c}$.

2. Бойко Н.I. Розвиток творчих здібностей молодших школярів засобами образотворчого мистецтва. Таврійський вісник освіти. 2013. №4 (44). C. 117-121.

3. Кельм С.В.Нетрадиційні уроки образотворчого мистецтва: Програма творчої майстерні для вчителів образотворчого мистецтва. Черкаси, 2014. 56 с.

4. Красовська О. Дидактична структура та типи уроків образотворчого мистецтва у змісті професійної підготовки майбутніх учителів початкової школи. Нова педагогічна думка. 2014. № 1. С. 73-77.

5. Криворучко Ю. М. Педагогічні умови формування готовності майбутнього вчителя до розвитку художньо-творчих здібностей молодших школярів. Науковий часопис НПУ імені М. П. Драгоманова. 2007. №6. С. 116-121. 
6. Ликова И. Изобразительная деятельность в учебном заведении. Москва, 2009. 230 с.

7. Мужикова I.M. (2002) Педагогічні умови підготовки вчителів початкових класів до викладання образотворчого мистецтва. Наука $i$ сучасність. 2002. № 35. С. 138-144.

8. Обертас Т.С. Розвиток творчих здібностей молодших школярів засобами образотворчого мистецтва. Таврійський вісник освіти. 2014. №1(45). С. 120-125.

9. Падалка Г.М. Педагогіка мистецтва. Теорія і методика викладання мистецьких дисциплін. К.: Освіта України, 2008. 274 с.

10. Сухорукова Г. Образотворче мистецтво 3 методикою викладання в загальноосвітньому навчальному закладі. К. : Видавничий Дім “Слово”, 2010.376 с.

11. Юркова Н. (2012) Рисование мыльной пеной, крашенными опилками, на самоклеющейся пленке. Обруч. 2012. №2. С. 69-71.

12. Ясеницька Ж., Савчин Г. (2014) Сучасні технології художньо-творчого розвитку учнів. Молодь і ринок. 2014. №8. С. 115-120.

\section{REFERENCES}

1. Banduristyy, F. (2001). Optimizatsiya obucheniya khudozhestvennomu proektirovaniyu $v$ sisteme spetsialnoy podgotovki uchitelya izobrazitelnogo iskusstva $v$ pedvuzakh (universitetakh) [Optimization of teaching artistic design in the system of special training of the teacher of fine arts in the colleges (universities)]. Moscov, 315 p. [in Russian].

2. Boiko, N.I. (2013). Rozvytok tvorchykh zdibnostei molodshykh shkoliariv zasobamy obrazotvorchoho mystetstva [Development of creative abilities of junior pupils by means of fine arts]. The Taurian Herald of Education, Vol. 4 (44), pp. 117-121. [in Ukrainian].

3. Kelm, S.V. (2014). Netradytsiini uroky obrazotvorchoho mystetstva: Prohrama tvorchoi maisterni dlia vchyteliv obrazotvorchoho mystetstva [Non-traditional lessons of fine art: A program for a creative workshop for teachers of fine arts]. Cherkasy, 56 p. [in Ukrainian].

4. Krasovska, O. (2014). Dydaktychna struktura ta typy urokiv obrazotvorchoho mystetstva u zmisti profesiinoi pidhotovky maibutnikh uchyteliv pochatkovoi shkoly [Didactic structure and types of fine art lessons in the content of future teacher training for elementary school]. New pedagogical thought, Vol. 1, pp. 73-77. [in Ukrainian].

5. Kryvoruchko, Yu. M. (2007). Pedahohichni umovy formuvannia hotovnosti maibutnoho vchytelia do rozvytku khudozhno-tvorchykh zdibnostei molodshykh shkoliariv [Pedagogical conditions of forming the readiness of the future teacher for the development of artistic and creative abilities of junior pupils]. Scientific journal of Mykhaylo Drahomanov National Pedagogical University, Vol. 6, pp. 116121. [in Ukrainian].

6. Likova, I. (2009). Izobrazitelnaya deyatelnost $v$ uchebnom zavedenii [Graphic activity in an educational institution]. Moscov, 230 p. [in Russian].

7. Muzhykova, I.M. (2002). Pedahohichni umovy pidhotovky vchyteliv pochatkovykh klasiv do vykladannia obrazotvorchoho mystetstva [Pedagogical conditions for the preparation of primary school teachers for the teaching of fine arts]. Science and modernity, Vol.35, pp. 138-144. [in Ukrainian].

8. Obertas, T.S. (2014). Rozvytok tvorchykh zdibnostei molodshykh shkoliariv zasobamy obrazotvorchoho mystetstva [Development of creative abilities of junior pupils by means of fine arts]. The Taurian Herald of Education, Vol. 1(45), pp. 120-125. [in Ukrainian].

9. Padalka, H.M. (2008). Pedahohika mystetstva. Teoriia i metodyka vykladannia mystetskykh dystsyplin [Pedagogy of art. Theory and methodology of teaching artistic disciplines]. Kyiv, 274 p. [in Ukrainian].

10. Sukhorukova, H. (2010). Obrazotvorche mystetstvo $z$ metodykoiu vykladannia $v$ zahalnoosvitnomu navchalnomu zakladi [Fine art with a method of teaching in a general education institution]. Kyiv, 376 p. [in Ukrainian].

11. Yurkova, N. (2012) Risovanie mylnoy penoy, krashennymi opilkami, na samokleyushcheysya plenke [Drawing with soap foam, painted sawdust, on selfadhesive film]. Obruch, Vol. 2, pp. 69-71. [in Russian].

12. Iasenytska, Zh. \& Savchyn, H. (2014). Suchasni tekhnolohii khudozhno-tvorchoho rozvytku uchniv [Modern technologies of artistic and creative development of students]. Youth \& market, Vol. 8, pp. 115-120. [in Ukrainian].

Стаття надійшла до редакції 08.07.2019

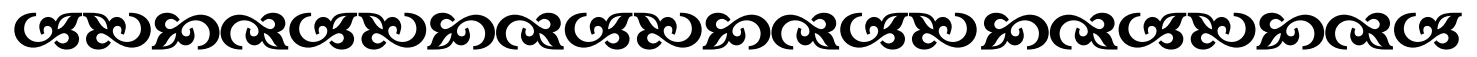

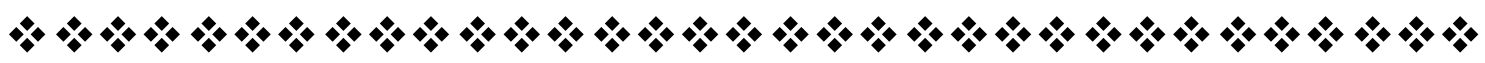

